\title{
Interaction between some Plant Extracts with some Antibiotics against Staphylococcus aureus from Chickens
}

\author{
Ashraf, A. Abd-El Tawab ${ }^{1}$, Ahmed A. Ammar ${ }^{2}$, Ahmed M. Hamouda ${ }^{3}$, \\ Wafaa A. EL Sebaey ${ }^{4}$, Salma S. El-Deen ${ }^{4}$ and Safinaz A.M. Elhawary ${ }^{5 *}$ \\ ${ }^{1}$ Department of Bacteriology, Immunology and Mycology, Faculty of Veterinary Medicine, \\ Benha University, Moshtoher, Qalyubiyagovernate, Egypt \\ ${ }^{2}$ Department of Bacteriology, Immunology and Mycology, Faculty of Veterinary Medicine, \\ Zagazig University, Zagazig, Sharkiagovernate, Egypt \\ ${ }^{3}$ Animal Health Research Institute Zagazig, Sharkiagovernate, Egypt \\ ${ }^{4}$ Animal Health Research, Dokki, Giza, Egypt \\ ${ }^{5}$ Faculty of Veterinary Medicine, Benha University, Qalyubiyagovernate, Egypt \\ *Corresponding author
}

\section{A B S T R A C T}

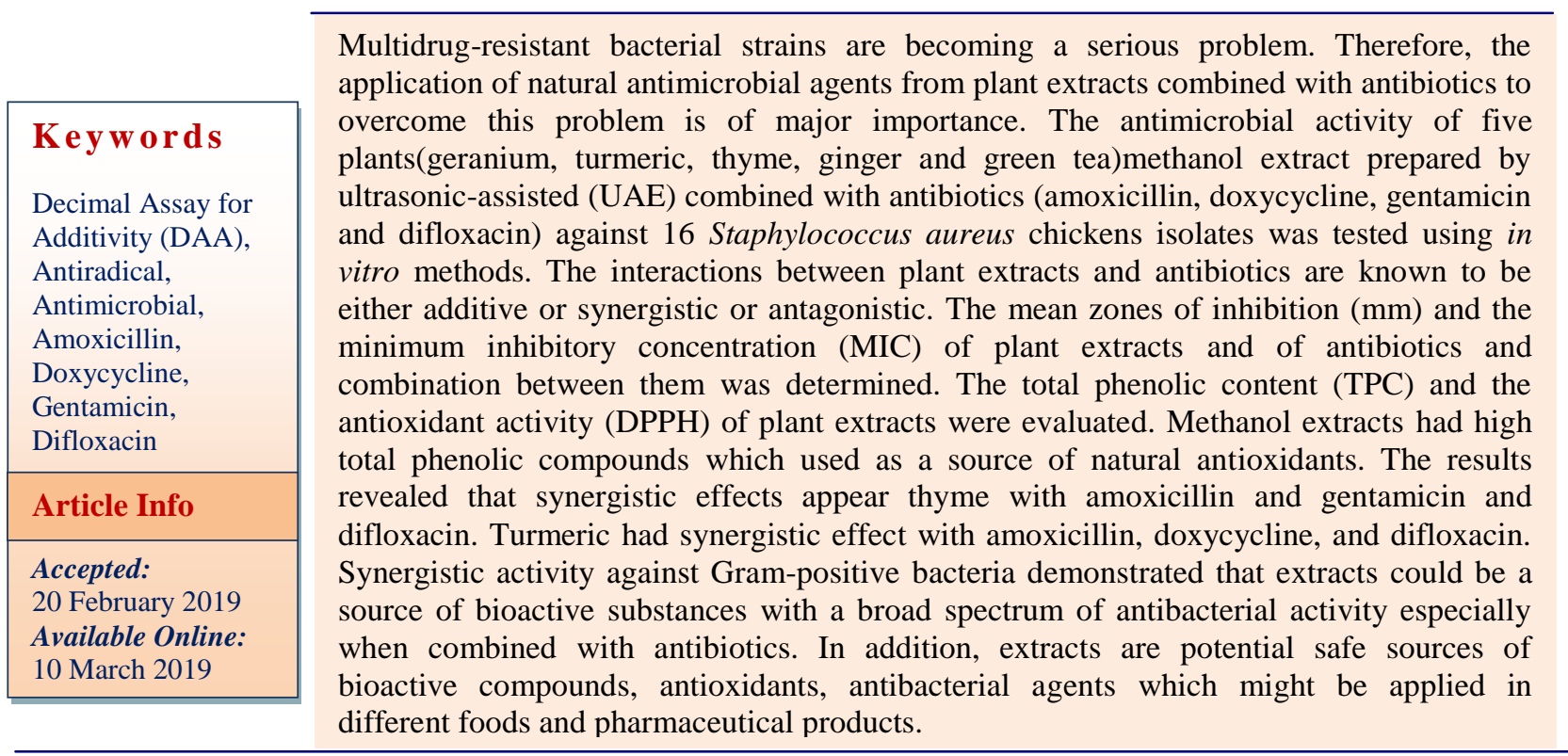

\section{Introduction}

The incorrect and overuse of existing antimicrobials was becoming a formidable threat in the fight against disease due to the emergence of multi-drug resistant strains (Lambert, 2000; Van Vuuren et al., 2009). Drug synergism between known antimicrobial 
agents and bioactive plant extracts is a novel concept and has been recently reported (Nascimento et al., 2000; Aqil et al., 2005; Betoni et al., 2006 and Mhanna and Adwan, 2008).

In the recent time, spread of multidrug resistance as a phenomenon among bacterial pathogens had been a major problem confronting the field of antibacterial chemotherapy (Stefanovic and Comic, 2012). To overcome this problem some medicinal plants as a source of multidrug resistance inhibitor were utilized in combination antimicrobial agents (Eze et al., 2013).

The Minimum Inhibitory Concentration (MIC) is the lowest concentration of an antimicrobial that will inhibit the visible growth of a microorganism by overnight incubation, usually reported as $\mathrm{mg} / \mathrm{L}$ (Delaquis et al., 2002).It represents a monitor resistance to antimicrobial agents and done by broth dilution methods (Handa et al., 2008).

Nowadays to overcome environmental pollution caused plant residues, numerous studies focused on recovering, recycling of plant residues as it has potential biological effects (Cioffi et al., 2010 and Gavaric et al., 2015). About $99 \%$ of residues after extraction rich with secondary metabolites and bioactive compounds e.g. natural antioxidants and phenolic compounds (Zhao and Gao, 2014) which play an important role in protection against infection, preventing oxidation and degenerative diseases (Singleton et al., 1965 and Valko et al., 2006). This study was carried out to evaluate the interaction of some plant extracts with some antibiotics against Staphylococcus aureus from chickens and determine minimal inhibitions concentration (MIC) for each antibiotics and plant extracts by using decimal assay for additivity (DAA) method to detect effect of interaction between antibiotics and plant extracts.

\section{Materials and Methods}

\section{Bacterial strains}

\section{Standard strain (ATCC)}

The tested microorganisms were provided from the culture collections of the Microbiological Department National Research Center (NRC) Dokki, Giza, Egypt. These include Staphylococcus aureus ATCC.

\section{Field strain}

Sixteen isolates out of 150 samples of clinical diseased chickens which isolated from different farms in Dakhliagovernate, and Sharkiagovernate was shown in Table 1. Under aseptic condition, samples were transferred to bacteriological laboratory for bacteriological examination.

\section{Plants}

\section{Plant materials}

Five plant including green tea (Camellia sinensis) leaves, thyme (Thymus vulgaris) leaves, ginger (Zingiber officinale) rhizomes, turmeric (Curcuma longa) rhizomes and geranium leaves (Pelargonium graveolens) leaves.

\section{Preparation of the ultrasonic-assist methanol $(80 \%)$ extract}

Modern techniques as extraction by ultrasound to overcome (time-solvent) consuming and increase extraction efficiency Betancount (2008) was shown in Table 2.

\section{Isolation and identification of the suspected bacteria}

Samples were identified by Gram staining, colony morphology, motility test, coagulase test, catalase reaction, Vogues- Proskaur test, 
and sugar fermentation, as described by Barrow and Gelthan (1993) and Harrigan (1998).

\section{Antimicrobial susceptibility testing}

\section{Disk Diffusion Method}

According to guidelines set by the Clinical Laboratory Standards Institute (2011), (CLSI2011) the diameters of the zones of inhibition were measured in millimeter and classified as resistant, intermediate or sensitive and done to plant extract and, antibiotics alone and also to combination between them by disk diffusion method to detect the effect of ten standard antibiotic discs (Oxoid®) and five selected extracts against Staphylococcus aureus.

\section{Minimal inhibitory concentration (MIC)}

The isolated strain matches the 0.5 McFarland

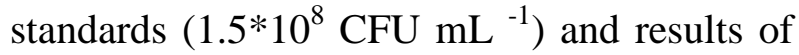
antibiotics and plant extracts showed no visible bacterial growth considered as MIC and interpreted with recommendations of the National Committee for Clinical Laboratory standards (2011).

Evaluation of the combined activity of antibiotics and extracts using Decimal Assay for Additivity (DAA)

The evaluation was performed as described by Sanders et al., (1993) to detect end point for additivity so that interactions greater or less than additivity defined as synergism and antagonism respectively.

\section{Determination of total phenolic compounds (TPC)}

TPC was measured using UV spectrophotometer according to Škerget et al., (2005) using Folin-Ciocalteu reagent. The results were expressed as $\mathrm{mg}$ gallic acid equivalents (GAE) per gram of dry weight (mg GAE $\mathrm{g}^{-1} \mathrm{DW}$ ) using a calibration curve and the yield of extracts $(\mathrm{g} / 100 \mathrm{~g})$.

\section{Antioxidant 2,2-diphenyl-1-picrylhydrazyl (DPPH) radical-scavenging activity}

The ability of extracts for electron donation was measured by bleaching of the purple colored solution of DPPH (2,2-diphenyl-1picrylhydrazyl) to the yellow color as described by Gulcin et al., (2004). The color intensity varies according to the amount of oxidant in the sample. The absorbance of this color was measured spectrophotometrically at $530 \mathrm{~nm}$ (Dikilitas et al., 2011).

\section{Results and Discussion}

The study focused on the prevalence of Staphylococcus aureus and resistance patterns in Staphylococcus aureus. A total of 150 samples were aseptically in farms located in Sharkia and Dakahlia governorates with bacteriological examination. Positive samples revealed the presence of 16 Staphylococcosis out of 150 specimens and isolates with percentages of $(10.6 \%)$ respectively in Table 1.

For further identification of Gram positive biochemical tests such as catalase test and coagulase test were used under standard conditions as discussed in the methods in Table 3. Staphylococcus aureus showed positive results with catalase test, also positive result with coagulase.

Antimicrobial susceptibility testing showed the highest sensitivity rate of Staphylococcus aureus strains that recorded to amoxycillin (6\%) of sensitive strains, the highest intermediate with doxycycline and gentamicin (6\%) of intermediate strains and the highest resistant with colistin, streptomycin, and cefotaxeme $(16 \%, 15 \%$ and $12 \%$ respectively) 
of the resistant strains which shown in Table 4.

As for Staphylococcus aureus, the extract of turmeric with lowest concentration had an inhibition zone of $11 \mathrm{~mm}$, the green tea with lowest concentration had an inhibition zone of $14 \mathrm{~mm}$, the thyme with lowest concentration had an inhibition zone of $13 \mathrm{~mm}$, the geranium with lowest concentration had an inhibition zone of $10 \mathrm{~mm}$ and ginger with lowest concentration had an inhibition zone $12 \mathrm{~mm}$ against field isolated Staphylococcus aureus strains in Table 5.

On the other hand antibiotics (amoxicilin, doxycycline, gentamicin, and difloxacin) exhibited different inhibition zone from (14 to $15 \mathrm{~mm}$ on field isolated Staphylococcus aureus strains) for amoxicilin, from (15 to17 mm on field isolated Staphylococcus aureus strains), for doxycycline from (12 to $16 \mathrm{~mm}$ on field isolated Staphylococcus aureus strains), while (12 $\mathrm{mm}$ on field isolated Staphylococcus aureus strains) for gentamicin, finally (16 to19 $\mathrm{mm}$ on field isolated Staphylococcus aureus strains) for difloxacin which shown in Table 5.

Five plant extracts were subjected to a broth macrodilution assay and after twenty four hours observation of Staphylococcus aureus growth to determine the MIC values.

As the MIC of geranium was $(4 \mu \mathrm{g} / \mathrm{mL}$ on field isolated Staphylococcus aureus and $2 \mu \mathrm{g} /$ $\mathrm{mL}$ on standard strain of Staphylococcus aureus $)$, green tea was $(16 \mu \mathrm{g} / \mathrm{mL}$ on field isolated Staphylococcus aureus and $4 \mu \mathrm{g} / \mathrm{ML}$ on standard strain of Staphylococcus aureus), ginger was $(16 \mu \mathrm{g} / \mathrm{ML}$ and $4 \mu \mathrm{g} / \mathrm{mL}$ on standard strain of Staphylococcus aureus), thyme was $\quad(4 \mu \mathrm{g} / \mathrm{mL}$ on field isolated Staphylococcus aureus and $1 \mu \mathrm{g} / \mathrm{ML}$ on standard strain of Staphylococcus aureus) and turmeric was $(16 \mu \mathrm{g} / \mathrm{mL}$ on field isolated Staphylococcus aureus and $2 \mu \mathrm{g} / \mathrm{mL}$ on standard strain of Staphylococcus aureus) which shown in Table 6. In this study each four antibiotics was subjected to a broth macro dilution assay and after twenty four hours observation of bacterial growth to determine the minimal inhibition concentration (MIC) values on Staphylococcus aureus.

MIC values amoxicillin was $(8 \mu \mathrm{g} / \mathrm{ml}$ for Staphylococcus aureus and $4 \mu \mathrm{g} / \mathrm{mL}$ on standard strain of Staphylococcus aureus), doxycycline was $\quad(16 \mu \mathrm{g} / \mathrm{ml}$ for on field isolated Staphylococcus aureus and $2 \mu \mathrm{g} / \mathrm{mL}$ on standard strain of Staphylococcus aureus), and gentamicin was $\quad(16 \mu \mathrm{g} / \mathrm{ml}$ on field isolated Staphylococcus aureus and $4 \mu \mathrm{g} / \mathrm{mL}$ on standard strain of Staphylococcus aureus) and difloxacin was $\quad(0.5 \mu \mathrm{g} / \mathrm{ml}$ on field isolated Staphylococcus aureus and $0.125 \mu \mathrm{g} /$ $\mathrm{mL}$ on standard strain of Staphylococcus aureus)which shown in Table 7.

Antimicrobial activities of methanol different plant extracts in combination with antimicrobial agents on selected Staphylococcus aureus isolates as Interactions between these components lead to antagonistic, additive and synergistic effects as additive effect was observed when the combined effect was equal to the sum of the individual effects, antagonism was observed when the effect of one or both compounds was less when they were applied together than when individually applied and Synergism was observed when the effect of the combined substances was greater than the sum of the individual effects.

Results of synergy between antibiotics/plant extracts on Staphylococcus aureus were presented in Table 8.

Amoxicillin showed synergistic action in combination of with thyme by level $(7: 3)$ and by (5:5) while with turmeric by level (7:3), 
according to doxycycline showed synergistic action with geranium by level (7:3), (6:4) and by $(5: 5)$ and with turmeric by level $(7: 3)$ and (6:4), also gentamicin recorded synergistic action in combination of with thyme by level (7:3), (6:4) and by (5:5). Finally difloxacin reported synergistic action in combination of with ginger by level $(7: 3),(6: 4)$ and by $(5: 5)$ and with turmeric by level (7:3), (6:4) and by (5:5) and with thyme by level (5:5).

According to total phenolic compound, Table 9 illustrated that thyme had high phenolic compounds than genarium and finally green tea, on other hand ginger and turmeric had nearly the same results with respective values of 253.01, 219.38, 190.33, 43.96 and 41.92 mg GAE $\mathrm{g}^{-1}$ extract TPC expressed as Gallic acid equivalent (GAE) was calculated using the following linear equation based on the calibration curve.

According to DPPH result, ginger and turmeric revealed higher extension than green tea than geranium, Also thyme extract has shown lower extent of DPPH neutralization $(\mathrm{EC} 50=128.49 \mathrm{mg} / \mathrm{mL})$ than oil obtained in our investigation as show in Figure 1.

Table.1 Number of Staphylococcus aureus isolates obtained from various specimens collected from different localities in Sharkia and Dakalia

\begin{tabular}{|c|c|c|c|}
\hline \multicolumn{2}{|r|}{ Locality } & No. of cases & Staphylococcus \\
\hline \multirow{2}{*}{ 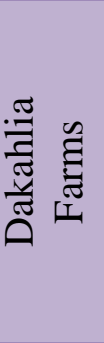 } & $\begin{array}{c}\text { Private farms } \\
\text { (Mahtet Elsalam, } \\
\text { Mahtet ElAml, } \\
\text { Tawonya) }\end{array}$ & 30 & 5 \\
\hline & $\begin{array}{l}\text { Private farms (Gamsa, } \\
\text { Sherbin) }\end{array}$ & 20 & $\mathbf{0}$ \\
\hline \multirow{2}{*}{ 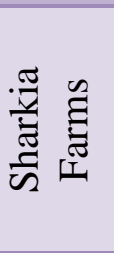 } & $\begin{array}{c}\text { Farms in } \\
\text { Sharkiagovernate } \\
\text { Elsalehia project }\end{array}$ & 40 & 5 \\
\hline & $\begin{array}{l}\text { Private farms in } \\
\text { Sharkiagovernate }\end{array}$ & 60 & \\
\hline \multicolumn{2}{|r|}{ Total } & 150 & $16(10.6 \%)$ \\
\hline
\end{tabular}

Table.2 List of the methanolic extract obtained from different plant parts $\mathrm{g} / \mathrm{ml}$ spices in Stock solution

\begin{tabular}{|c|c|c|c|c|c|}
\hline Scientific name & Family & Local name & $\begin{array}{c}\text { Wt. of extract } \\
\text { in tube }(\mathrm{g})\end{array}$ & $\begin{array}{c}\text { Wt. of empty } \\
\text { tube }(\mathrm{g})\end{array}$ & $\begin{array}{c}\text { Total Wt. of } \\
\text { extract }(\mathrm{g})\end{array}$ \\
\hline Pelargonium graveolens & Geraniaceae & Geranium & 138.0542 & 134.5216 & 3.53 \\
\hline Camellia sinensis & Theaceae & Green tea & 172.3789 & 169.9189 & 8.9 \\
\hline Zingiberofficinale & Zingiberiaceae & Ginger & 177.5154 & 176.9858 & 1.02 \\
\hline Thymus vulgaris & Thymeleaceae & Thyme & 191.9960 & 187.3328 & 4.66 \\
\hline Curuma longa & Zingiberiaceae & Turmeric & 193.6245 & 192.6999 & 0.42 \\
\hline
\end{tabular}


Table.3 Culture and biochemical identification of Gram-positive isolates Staphylococcus aureus

\begin{tabular}{|c|c|}
\hline Nutrient agar & $\begin{array}{l}\text { smooth, had a low convex profile with an entire edge and pigmented } \\
\text { yellowish colonies }\end{array}$ \\
\hline Haemolytic activity & B-hemolytic \\
\hline Mannitol salt agar & yellow halo zone surrounding their growth \\
\hline Baired Parker agar & black, shiny, convex and surrounded by a clear zone \\
\hline E-Pigmentation & golden yellow pigment on milk agar \\
\hline Catalase test & + \\
\hline Coagulase test & + \\
\hline Total NO. & 16 \\
\hline$\%$ of isolate & $10.6 \%$ \\
\hline
\end{tabular}

Table.4 Antimicrobial susceptibility on Staphylococcus aureus by agar disc diffusion method

\begin{tabular}{|c|c|c|c|c|}
\hline $\begin{array}{c}\text { Antimicrobial } \\
\text { agents }\end{array}$ & $\begin{array}{c}\text { Antibiotic } \\
\text { disc/conc. }(\boldsymbol{\mu g})\end{array}$ & S & I & R \\
\hline Amoxicillin & AML-25 $\mu \mathrm{g}$ & 6 & 4 & 6 \\
\hline Colistin & $\mathrm{CT}-10 \mu \mathrm{g}$ & 0 & 0 & 16 \\
\hline Difloxacin & $\mathrm{INN}-5 \mu \mathrm{g}$ & 5 & 5 & 6 \\
\hline Doxycycline & $\mathrm{DO}-30 \mu \mathrm{g}$ & 4 & 6 & 6 \\
\hline Gentamicin & $\mathrm{CN}-10 \mu \mathrm{g}$ & 3 & 6 & 7 \\
\hline Erythromycin & $\mathrm{E}-15 \mu \mathrm{g}$ & 5 & 5 & 5 \\
\hline Flurophenicol & $\mathrm{F}-30 \mu \mathrm{g}$ & 2 & 4 & 10 \\
\hline Cefotaxime & $\mathrm{CTX}-30 \mu \mathrm{g}$ & 1 & 3 & 12 \\
\hline Streptomycin & $\mathrm{S}-10 \mu \mathrm{g}$ & 0 & 1 & 15 \\
\hline
\end{tabular}

$\mathrm{R}$ (resistance), $\mathrm{S}$ (susceptibility), I (intermediate)

Table.5 Zone of inhibition ( $\mathrm{mm}$ ) of antibiotics and plant extracts alone and in combination on field and standard strains of Staphylococcus aureus

\begin{tabular}{|c|c|c|c|c|c|c|c|c|c|}
\hline Isolates & \multicolumn{9}{|c|}{ Inhibition zone (mm) } \\
\hline \multirow[b]{2}{*}{ Plant } & \multirow{2}{*}{$\begin{array}{l}\text { Plant } \\
\text { alone }\end{array}$} & \multicolumn{4}{|c|}{ Antibiotics alone } & \multicolumn{4}{|c|}{ Combination } \\
\hline & & $\begin{array}{c}\text { AML/ } \\
18(\mathrm{~mm})\end{array}$ & $\begin{array}{c}\text { Do/ } 18 \\
(\mathrm{~mm})\end{array}$ & $\begin{array}{c}\mathrm{CN} / \\
15 \\
(\mathrm{~mm})\end{array}$ & $\begin{array}{c}\text { INN/ } \\
22 \\
(\mathrm{~mm})\end{array}$ & AML & $\mathrm{DO}$ & $\mathrm{CN}$ & INN \\
\hline geranium & 10 & 16 & 14 & 12 & 17 & 16 & 19 & 13 & 20 \\
\hline green tea & 13 & 15 & 13 & 12 & 16 & 13 & 12 & 10 & 14 \\
\hline ginger & 12 & 15 & 12 & 12 & 16 & 16 & 17 & 13 & 22 \\
\hline thyme & 14 & 17 & 16 & 12 & 17 & 18 & 16 & 17 & 22 \\
\hline turmeric & 11 & 15 & 13 & 12 & 19 & 19 & 18 & 13 & 22 \\
\hline
\end{tabular}

AML: amoxicillin. DO: doxycyclin.

$\mathrm{CN}$ : gentam INN: difloxacin 
Table.6.Minimum inhibitory concentration (MIC) of plant extracts on Staphylococcus aureus

\begin{tabular}{|c|c|c|}
\hline \multirow{2}{*}{ Plants } & $\begin{array}{c}\text { Staphylococcus } \\
\text { aureus }\end{array}$ & $\begin{array}{c}\text { MIC } \\
\boldsymbol{\mu g} / \mathbf{~ m l}\end{array}$ \\
\hline \multirow{2}{*}{ Geranium } & Field Strain & 4 \\
\cline { 2 - 3 } & Standard strain & 2 \\
\hline \multirow{2}{*}{ green tea } & Field Strain & 16 \\
\cline { 2 - 3 } & Standard strain & 4 \\
\hline \multirow{2}{*}{ Ginger } & Field Strain & 16 \\
\cline { 2 - 3 } & Standard strain & 8 \\
\hline \multirow{2}{*}{ Thyme } & Field Strain & 4 \\
\cline { 2 - 3 } & Standard strain & 1 \\
\hline \multirow{2}{*}{ Turmeric } & Field Strain & 16 \\
\cline { 2 - 3 } & Standard strain & 2 \\
\hline
\end{tabular}

Table.7 Minimum inhibitory concentration (MIC) of antibiotics on Staphylococcus aureus (field and standard strains)

\begin{tabular}{|c|c|c|}
\hline Antibiotic & $\begin{array}{c}\text { Staphylococcus } \\
\text { aureus }\end{array}$ & $\begin{array}{c}\mathrm{MIC} \\
\mu \mathrm{g} / \mathrm{ml}\end{array}$ \\
\hline \multirow{2}{*}{$\mathbf{A M L}(\mathbf{2 0 \%})$} & Field strain & 8 \\
\cline { 2 - 3 } & Standard strain & 4 \\
\hline \multirow{2}{*}{$\mathbf{D O}(\mathbf{2 0 \%})$} & Field strain & 16 \\
\hline \multirow{2}{*}{$\mathbf{C N}(\mathbf{1 0 \%})$} & Standard strain & 2 \\
\hline \multirow{2}{*}{$\mathbf{I N N}(\mathbf{1 0} \%)$} & Field strain & 16 \\
\hline & Standard strain & 4 \\
\hline & Field strain & 0.5 \\
\hline
\end{tabular}

AML: amoxicillin. DO: doxycyclin.

$\mathrm{CN}$ : gentamicin. INN: difloxacin 
Table.8 Combination activity of antibiotics with plant extracts using Decimal Assay for Additivity (DAA)

\begin{tabular}{|c|c|c|c|c|c|c|}
\hline \multirow[t]{2}{*}{ Plant extracts } & \multirow[t]{2}{*}{ Antibiotics } & \multicolumn{3}{|c|}{ DAA } & \multirow{2}{*}{$\begin{array}{c}\text { MIC } \\
\text { AB alone }\end{array}$} & \multirow[t]{2}{*}{ effect } \\
\hline & & $\mathrm{AB}$ & $\mathrm{E}$ & DAA & & \\
\hline \multirow[t]{3}{*}{ Geranium } & \multirow[t]{3}{*}{ a) doxycycline } & 7 & 3 & 8 & 16 & \multirow[t]{3}{*}{ Synergy (S) } \\
\hline & & 6 & 4 & 8 & 16 & \\
\hline & & 5 & 5 & 8 & 16 & \\
\hline \multirow[t]{6}{*}{ Thyme } & \multirow[t]{2}{*}{ a)amoxycillin } & 7 & 3 & \multirow[t]{2}{*}{4} & \multirow[t]{2}{*}{8} & \multirow[t]{2}{*}{ Synergy (S) } \\
\hline & & 5 & 5 & & & \\
\hline & \multirow[t]{3}{*}{ b) gentamicin } & 7 & 3 & \multirow[t]{3}{*}{4} & \multirow[t]{3}{*}{16} & \multirow[t]{4}{*}{ Synergy (S) } \\
\hline & & 6 & 4 & & & \\
\hline & & 5 & 4 & & & \\
\hline & C) difloxacin & 5 & 5 & 0.25 & 2 & \\
\hline \multirow[t]{6}{*}{ Turmeric } & a) amoxycillin & 7 & 3 & 0.25 & 0.5 & \multirow[t]{6}{*}{ Synergy (S) } \\
\hline & b) doxycycline & 7 & 3 & 2 & 4 & \\
\hline & & 6 & 4 & & & \\
\hline & \multirow[t]{3}{*}{ c) difloxacin } & 7 & 3 & 0.25 & \multirow[t]{3}{*}{2} & \\
\hline & & 6 & 4 & 0.5 & & \\
\hline & & 5 & 5 & 0.5 & & \\
\hline \multirow[t]{3}{*}{ Ginger } & \multirow[t]{3}{*}{ a) difloxacin } & 7 & 3 & 0.5 & \multirow[t]{3}{*}{2} & \multirow[t]{3}{*}{ Synergy (S) } \\
\hline & & 6 & 4 & 1 & & \\
\hline & & 5 & 5 & 0.5 & & \\
\hline
\end{tabular}

Table.9 Yield of extracts $(\mathrm{g} / 100 \mathrm{~g})$ for different plants

\begin{tabular}{|c|c|c|c|}
\hline Plants & extract yield & \% Extract & TPC mg GAE/g extract \\
\hline Green tea & 8 & 40 & 190.33 \\
\hline Thyme & 4.66 & 23.3 & 253.01 \\
\hline Ginger & 1.02 & 5.1 & 43.96 \\
\hline Turmeric & 0.42 & 2.1 & 41.92 \\
\hline Geranium & 3.53 & 17.65 & 219.38 \\
\hline
\end{tabular}

GAE: gallic acid equivalents.

TPC: Total phenolic compound 
Figure.1 Antioxidant DPPH ${ }^{*}$ radical-scavenging activity

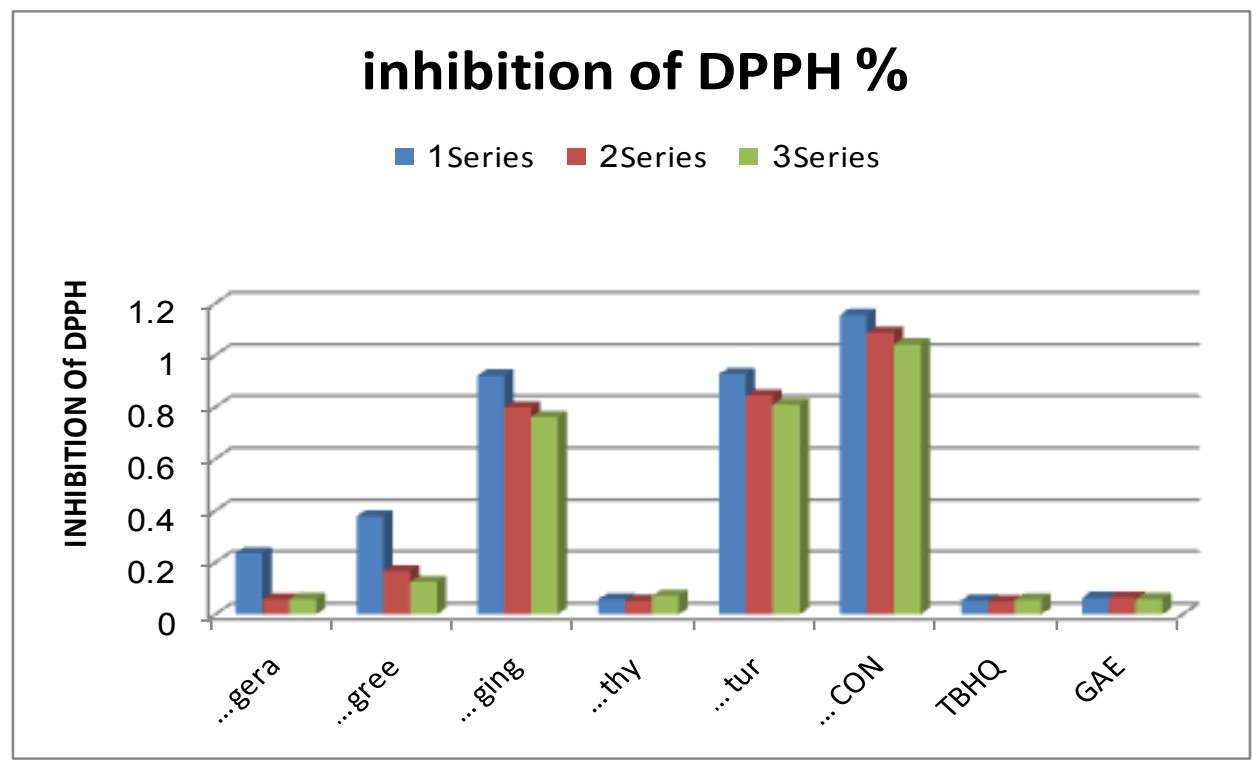

GAE: gallic acid equivalents

TBHQ:Tert-butyl hydroquinone

Staphylococcus aureus was recorded from chickens in Dakahlia and Sharkia governorates in Egypt in percentage 10.6\% (16 out of 150) which was nearly coordinated with Lee et al., (2003) who recorded Staphylococcus aureus from feces, feed, joint and trachea of chickens, and isolated Staphylococcus aureus from each sample in the percentage of $13 \%, 5.7 \%, 11.1 \%, 27.7 \%$, $13.5 \%$, respectively.

Biochemical tests as catalase test and coagulase test showed positive results with tested strains this results agreed with Normannoa et al., (2004).

As for Staphylococcus aureus the extract of turmeric with the lowest concentration had a inhibition zone of ranged of $11 \mathrm{~mm}$, the green tea with the lowest concentration had a inhibition zone of $14 \mathrm{~mm}$, the thyme with the lowest concentration had a inhibition zone of $13 \mathrm{~mm}$, geranium with the lowest concentration had a inhibition zone of $10 \mathrm{~mm}$ and the ginger with the lowest concentration had a inhibition zone of $12 \mathrm{~mm}$ showed in. So this result agreed with Hamed et al., (2013) in turmeric, Archana and Abraham (2011) in green tea, Fayed et al., (2013) in thyme, while in geranium Oulkheir (2017) disagreed with us, finally in ginger was not parallel to Kredi (2016).

Our results suggested that thyme extract could be combined with antibiotics like amoxicillin, gentamicin and difloxacin as it has been successful in combating Staphylococcus aureus.

As extracts from turmeric shows synergistic effects against Staphylococcus aureus compared to doxycycline, difloxacin antibiotics and this agreed with Teow et al., (2015).

On the other hand in this study demonstrated synergistic effects of ginger amoxicillin and difloxacin against Staphylococcus aureus, these results were similar to Shekhan et al., (2012). 
There were antagonist effects results of green tea with difloxacin similar to Tuysuz et al., (2017).

The study showed that geranium and doxycycline combinations were synergistic against Staphylococcus aureus. Rosato et al., (2007) illustrated that there were synergistic effects of geranium and gentamicin combination against Staphylococcus aureus, these results disagreed with our study results.

Activity of extract compared to unstable oil is probably due to presence of nonvolatile phenol compounds. In addition, some of the compounds with a different polarity, which are present in very small amounts in the extract, are also able to contribute to better an oxidative activity of extract. Some compounds can originate in extract during hydrolysis or other processes of decomposition. Some chemical reactions initiated by heating can also drive up to activities changes of complex extract, composed of a number of compounds with different chemical and physical properties (Singh et al., 2005).

The free radical activity of the plant extracts was performed according to the DPPH free radical method, described by Brand-Williams et al., (1995).

It can be noticed that the degree of DPPH neutralization depended on incubation time, for all investigated concentrations of oil. The highest degree of DPPH radicals' neutralization is for 60 minutes incubation.

In conclusion, the demonstration of synergistic activity by the antibiotic and extracts against Gram-positive bacteria is an indication that plants can be a source of bioactive substances that could possess broad spectrum of activity most especially when it is combined with antibiotic. Thus, there is increasing need for researchers to investigate the synergistic capacity of plants or other natural products, independent of the antimicrobial activity. These findings also suggested that the need for understanding of synergism mechanism is fundamental to development of pharmacological agents to treat diseases by various bacteria using medicinal plants in combination with antibiotics.

\section{References}

Archana, S. and Abraham, J. (2011). Comparative analysis of antimicrobial activity of leaf extracts from fresh green tea, commercial green tea and black tea on pathogens. Journal of Applied Pharmaceutical Science, 1(8): 149-152.

Aqil, F., Khan, M.S.A., Owais, M. and Ahmad, I. (2005), Effect of certain bioactive plant extracts on clinical isolates of $\beta$-lactamase producing methicillin resistant Staphylococcus aureus. Journal of Basic Microbiology, 45, 106-114.

Barrow, G. I. and Gelthan, R.K.A. (1993). Cawan and steels Manual for the identification of medical bacteria London. Cambridge University Press.

Betancourt, AO. (2008). Analyse, extraction et récupération de poly-3 hydroxybutyrate présent dans la biomasse. Université du Québec à Montréal Thesis, pp. 45-55.

Betoni, J.E.C., Mantovani, R.P., Barbosa, L.N., Di Stasi, L.C. and Fernandes, J.A. (2006). Synergism between plant extract and antimicrobial drugs used on Staphylococcus aureus diseases. Mem. Inst. Oswaldo Cruz. Rio de Janeiro101(4): 387-390.

Bryngelson, S., Mannerstedt-Fogelfors, B., Kamal Eldin, A., Andersson, R. and Dimberg, L.H. (2002). Lipids and antioxidants in groats and hulls of 
Swedish oats (Avena sativa L.). J Sci Food Agric. 82, 606-614.

Cioffi M.B., Martins C. and Bertollo LAC.(2010). Chromosomal spreading of associated transposable elements and ribosomal DNA in the fish Erythrinus erythrinus. Implications for genome change and karyo evolution in fish. BMC Evolutionary Biology 10, 271.

CLSI (2011).Clinical and Laboratory Standards Institute. Performance Standards for Antimicrobial Susceptibility Testing; Twenty-First Informational Supplement. CLSI document M100-S21. Clinical and Laboratory Standards Institute, 940 West Valley Road, Suite 1400, Wayne, Pennsylvania 19087 USA, 2011.

Delaquis, P.J., Stanich, K., Girard, B. and Mazza, G. (2002). Antimicro- bial activity of individual and mixed fractions of dill, cilantro, coriander and eucalyptus essential oils. Int. J. Food Microbiol. 74, 101-109.

Diep, B.A., Gill, S.R., Chang, R.F., Phan, T.H., Chen, J.H., Davidson, M.G, Lin, F., Lin, J., Carleton, H.A., Mongodin, E.F., Sensabaugh, G.F. and PerdreauRemington, F. (2006). Complete genome sequence of USA300, an epidemic clone of communityacquired methicillin-resistant Staphylococcus aureus. Lancet 367, 731-739.

Dikilitas, M., Guldur, M.E., Deryaoglu, A., Erel, O., (2011). Antioxidant and oxidant levels of pepper (Capsicum annuum cv. 'Charlee') infected with pepper mild mottle virus. Not. Bot. HortiAgrobo.39, 58-63.

Eze, E., Oruche, N., and Eze, C. (2013). Interaction of the extracts of three medicinal plants with antibiotics against some antibiotic resistant bacteria. Academic Journals 8(28): 1360-1367.

Fayad, N.K., AL- Obaidi, O.H.S. and AlNoor, T.H. (2013). Water and alcohol extraction of thyme plant (Thymus vulgaris) and activity study against bacteria, tumors and used as antioxidant in margarine manufacture. Innovative Systems Design and Engineering 4(1): 41-51.

Gulcin, I., Kufrevioglu, O.I., Oktay, M. and Buyukokuroglu, M.E. (2004). Antioxidant, antimicrobial, antiulcer and analgesic activities of nettle (Urtica dioica L.). J. Ethnopharmacolo. 90, 205-215.

Hamed, O.A., Mehdawi, N., Taha, A.A., Hamed, E.M., Al-Nuri, M.A. and Hussein, A.S. (2013). Synthesis and antibacterial activity of novel curcumin derivatives containing heterocyclic moiety. Iran J Pharm Res.12(1): 47-56.

Handa, S.S., Khanuja, S.P.S., Longo, G. and Rakesh, D.D. (2008). Extraction Technologies for Medicinal and Aromatic Plants, ( $1^{\text {st }}$ edn), no. 66. Italy: United Nations Industrial Development Organization and the International Centre for Science and High Technology.

Harrigan, W.F. (1998). Laboratory methods in food Microbiology, $3^{\text {rd }}$ Edn, Academic press, San Digo London, Boston, New york, Sydney Toront.

Kredi, D., (2016). Improving interfaces for nerve repair Improving interfaces for nerve repair. $\mathrm{PhD}$ thesis.

Lambert, R.J.W. (2000). Susceptibility testing: inoculum size dependency of inhibition using the Colworth MIC technique. J. Appl. Microbiol. 89, 275-279.

Lee, J.H. (2003). Methicillin (Oxacillin)resistant Staphylococcus aureus strains isolated from major food 
animals and their potential transmission to humans. Appl. Environ. Microbiol., 69(11): 64896494.

Mhanna M. and Adwan G. (2008). Synergistic effects of plant extracts and antibiotics on Staphylococcus aureus strains isolated from clinical specimens middle-east. Journal of Scientific Research, 3(3): 134-139.

Nascimento, G.G.F., Locatelli, J., Freitas, P.C. and Silva, G.L. (2000). Antibacterial activity of plant extracts and phytochemicals on antibiotic resistant bacteria. Braz. J. Microbiol. 31(4):247-256.

Normannoa, G., Firinub, A., Virgiliob, S., Mulab, G., Dambrosioa, A., Poggiub, A., Decastellic, L., Mionid, R., Scuotae, S., Bolzonif, G., DiGiannataleg, E., Salinettih, A. P, La-Salandrai, G., Bartolij, M., Zucconb, F., Pirinob, F., Siasb, S., Parisii, A. and Celanoa, G.V. (2004). Coagulase-positive Staphylococci and Staphylococcus aureus in food products marketed in Italy. International Journal of Food Microbiology98, 73-79.

Oulkheir, S., Aghrouch, M., El Mourabit, F., Dalha, F., Graich, H., Amouch, F., Ouzaid, K., Moukale, A. and Chadli (2017). Antibacterial activity of essential oils extracts from cinnamon, thyme, clove and geranium against a Gram negative and Gram positive Pathogenic Bacteria Journal of Diseases and Medicinal Plants3(2-1): 1-5.

Rosato, A., Vitali, C., Laurentis, N. D., Armenise, D. and Milillo, M., A. (2007). Antibacterial effects of some essential oils administered alone or in combination with norfloxacin. Phytomedicine 14, 727-732.

Sanders, C.C., Sanders, W.E., Jr and Moland,
E.S. (1993). Decimal assay for addictivity of drugs permits delineation of synergy and antagonism. Antimicrob. Agents Chemother 37, 260-264.

Shekhan, M. I. and Al-Hussaini, J. A. A. S. (2012). Study of the inhibitory effect of the ethanolic extracts of Coriandrum sativum, Vitis vinifera, and Zingiber officinale on the growth of Staphylococcus aureus isolated from milk of cow infected with clinical mastitied. Bas. J. Vet. Res. 11(2): 93-107.

Singleton, V.L., and Rossi, J.A. (1965). Colorimetry of total phenolics with phosphomolybdic phosphotungstic acid reagents. Am J Enol Viticult 16, 144-158.

Škerget, M., Kotnik, P., Hadolin, M., RižnerHraš, A., Simonič, M. and Knez, Ž. (2005). Phenols, proanthocyanidins, flavones and flavonols in some plant materials and their antioxidant activities. Food Chem. 89, 191-198.

Stefanovic, O. and Comic, L. (2012). Synergistic Antibacterial Interaction between Melissa officinalis extracts and antibiotics. J. Appl. Pharmaceut. Sci.2(1):1-5.

Sun, T., Xu, Z., Wu, C. T., Janes, M. and Prinyawiwatkul W. (2007). Antioxidant activities of different colored sweet bell peppers (Capsicum annuum L.). J Food Sci72, 98-102.

Teow, S.Y. and Ali, S., A. (2015). Synergistic antibacterial activity of Curcumin with antibiotics against Staphylococcus aureus. Pak. J. Pharm. Sci. 28(6): 2109-14.

Tuysuz, et al., (2017). Antimicrobial activities of widely consumed herbal teas, alone or in combination with antibiotics: an in vitro study. Peer J. 5, e3467.

Valko, M., Rhodes, C. J., Moncol, J. and Izakovic, M. (2006). Free radicals, 
metals and antioxidants in oxidative stress-induced cancer. Mini-review. Chem. Biol. Interact. 160, 1-40.

Van-Vuuren, S.F., Suliman, S. and Viljoen, A.M. (2009). The antimicrobial activity of four commercial essential oils in combination with conventional antimicrobials. Wiley Online Library
48(4): 440-446.

Zhao, Y. and Gao, Y. (2014). Self-processing of ribozyme-flanked RNAs into guide RNAs in vitro and in vivo for CRISPR-mediated genome editing. $J$. Integr. Plant Biol. 56(4): 343-349.

\section{How to cite this article:}

Ashraf, A. Abd-El Tawab, Ahmed A. Ammar, Ahmed M. Hamouda, Wafaa A. EL Sebaey, Salma S. El-Deen and Safinaz A.M. Elhawary. 2019. Interaction between some Plant Extracts with some Antibiotics against Staphylococcus aureus from Chickens. Int.J.Curr.Microbiol.App.Sci. 8(03): 2386-2398. doi: https://doi.org/10.20546/ijcmas.2019.803.282 